\title{
In vitro selection of rock phosphate solubility by microorganism from Ultisols in South Sulawesi, Indonesia
}

\author{
Muh Jayadi ${ }^{1, ~ *, ~ B a h a r u d d i n ², ~ B a c h r u l ~ I b r a h i m ~}{ }^{1}$ \\ ${ }^{1}$ Department of Soil Science, Hasanuddin University, Makassar, Indonesia \\ ${ }^{2}$ Research Center for Biotechnology, Hasanuddin University, Makassar, Indonesia
}

\section{Email address:}

muh_jayadi_tanah@yahoo.com (M. Jayadi)

\section{To cite this article:}

Muh Jayadi, Baharuddin, Bachrul Ibrahim. In Vitro Selection of Rock Phosphate Solubility by Microorganism from Ultisols in South Sulawesi, Indonesia. American Journal of Agriculture and Forestry. Vol. 1, No. 4, 2013, pp. 68-73. doi: 10.11648/j.ajaf.20130104.14

\begin{abstract}
Phosphorus (P) is the second most required nutrient of plants, but its availability in ultisols is relatively low. Source of $\mathrm{P}$ can be found from rock phosphate (RP) which has low solubility level. Use of microbial solubilizing phosphate such as bacteria, fungi or combination of both is potential to increase availability of P. This research was aimed to find bacterial or fungal isolates that are high potential in solubilizing of RP. In vitro selection was conducted to obtain indigenous bacteria or fungi from Ultisols of South Sulawesi. Selection of microbes for their capability to solubate rock phosphate qualitatively, conducted through measuring the solubility index (SI) and solubility efficiency (SE) on pykovskaya solid medium and on National Botanical Research Institutes phosphate-bromophenol blue (NBRIP-BPB) medium. The results of this study indicated that from SI and SE highest values, four high potential isolates were selected namely, Aspergillus niger JTM 2, Bacillus sp JTM 3, Aspergillus niger JTM 6 and Pseudomonas sp JTM 10. Ability of solubilizing phosphate from the four isolates was then tested in liquid medium pikovskaya either in single or mixed combination. Solubilizing phosphate of RF was determined according to [1] method. The results of test on solid media indicate that Bacillus sp JTM 3 and Pseudomonas sp JTM 10 have SI and SE higher than both Aspergillus niger JTM 2 and Aspergillus niger JTM 6. Futhermore, test on Pikovskaya liquid media confirmed that Aspergillus niger JTM 6 and Pseudomonas sp JTM 10 gives the higher results than other single isolates and control, whereas the combination of isolates Bacillus sp JTM 3 and Aspergillus niger JTM 2 indicated significantly higher solubilizing phosphorus production than all other treatments.
\end{abstract}

Keywords: In Vitro, Mixture Isolates, Pikovskaya Media, Rock Phosphate, Ultisols

\section{Introduction}

In Indonesia dry land which has acid reaction such as Ultisols, Oxisols and Inceptisols covers a total area of $65.49 \%$ (102.8 million ha). Ultisols soil is very potential to be used to increase food production due to its spread about $28.32 \%$ of available dry land [2]. The main characteristics of Ultisols are acid soil reaction $(\mathrm{pH})$, cation exchange capacity, base saturation and low $\mathrm{C}$ organic, aluminum content $(\mathrm{Al})$, iron $(\mathrm{Fe})$ and manganese $(\mathrm{Mn})$ and high phosphorous (P) fixation $[3,4]$. High fixation of $\mathrm{P}$ causes the element not available for plant. The existence of various constraints in the Ultisol soil can decrease real production.

Phosphor $(\mathrm{P})$ is the second nutrient element after nitrogen mostly required by plant. $\mathrm{P}$ is the main component of nucleic acid, phospholipid, ATP and some coenzymes. The effectiveness of using of phosphate fertilizer is very low only about $15 \%-20 \%$ [5] and $10-25 \%$ [6].
Rock phosphate (RP) as a source of $\mathrm{P}$ is not expensive, but the availability of $\mathrm{P}$ is low. Solubility of RP can be increased by phosphate solubilizing microorganism (PSM). Increasing RP solubility by microorganism is due to the lowering of $\mathrm{pH}$ and or organic acid excretion [7, 8]. Pseudomonas putida and Serratia mesenteroides were reported to increase solvable P at RP 6-19 times [9]. The ability of effective Pseudomonas and Bacilli in dissolving phosphate was also put forward by [10]. RP solubility is 10 times more was also obtained through the use of Aspergillus niger [11,12].

RP solubility mechanism by PSM is due to the effect of lowering $\mathrm{pH}$ and excreted organic acid by PSM $[8,13]$. Other researchers found that the P solubility was not always correlated negatively with $\mathrm{pH}$ [14-19]. Alam S., S. Khalil, N. Ayub and M. Rashid [20] found the existence of another factor besides organic acid in the solubility of P. Excreted organic acid can dissolve RP and or chelate cation from $\mathrm{P}$ 
to dissolve it [21].

Type and quantity of organic acid produced by PSM depends on strain, media composition, growth condition, etc, but most dominant PSM produces citric and oxalic acid $[20,13]$. Y. Sastro, D. Widianto and D. Shiddieq [22] found that dominant organic acid in Aspergillus niger was malate acid following citrate and oxalate. However, there was microorganism that did not produce organic acid but it could dissolve P [23]. Based on various mechanisms in the solubility of P, the ability of PSM in dissolving $\mathrm{P}$ is also different. Therefore the solubility of RP by single isolate or mixture of PSM isolates from fungi and bacteria that can synergize is hoped to be obtained in this study so that RP solubility can be more increased.

The main aim of this study is to obtain PSM isolate from Ultisol in Moncongloe which has high potential in dissolving RP through in vitro selection both in NBRIP-BPB solid media and pikovskaya liquid media.

\section{Materials and Methods}

\subsection{Isolation of PSM from Plant Rhizosphere}

Isolation of phosphate solvent was taken from the area of grass rhizosphere and cassava in Ultisol at Moncongloe village, Maros regency, Indonesia which is reacted to acid (pH 5.37) having low cation exchange capacity (26.77 cmolkg $\left.{ }^{-1}\right)$ and very low base saturation (15\%) and high Al saturation (24.62\%). From the rhizosphere area $10 \mathrm{~g}$ of soil was taken and then dissolved in $90 \mathrm{ml}$ sterile distilled water homogenized with vortex. Then $1 \mathrm{ml}$ soil solution was extracted and put into a test tube containing $9 \mathrm{ml}$ sterile distilled water until $10^{-5}$ dilution. The result of the dilution was then planted in picovskaya solid media. Pikovskaya solid media [24] contained tricalcium phosphate (rock phosphate) $5 \mathrm{~g}$, glucose $10 \mathrm{~g},\left(\mathrm{NH}_{4}\right) 2 \mathrm{SO}_{4} 0.5 \mathrm{~g}, \mathrm{NaCl} 0.2 \mathrm{~g}$, $\mathrm{MgSO}_{4} .7 \mathrm{H}_{2} \mathrm{O} 0.1 \mathrm{~g}, \mathrm{KCl} 0.2 \mathrm{~g}$, yeast extract $0.5 \mathrm{~g}, \mathrm{MnSO}_{4}$ trace, $\mathrm{FeSO}_{4} .7 \mathrm{H}_{2} \mathrm{O}$ trace, agar $15 \mathrm{~g}$, then were dissolved in $1000 \mathrm{ml}$ sterile water and incubated for 5 days. This isolate growing colony was reinoculated to be purified and tested further.

\subsection{PSM Ability Test to Dissolve Rock Phosphate in Solid Media}

Pure PSM was then tested its ability to dissolve $\mathrm{P}$ in selected pikovskaya media, but not all PSM growing on the media can produce halozone (clear zone). Therefore the test ability to dissolve $\mathrm{P}$ was also done by using media from the National Botanical Research Institutes Phosphate Bromophenol blue (NBRIP-BPB). NBRIP-BPB media have compositions $\mathrm{Ca}_{3}\left(\mathrm{PO}_{4}\right)_{2} 5 \mathrm{~g}$, glucose $10 \mathrm{~g}$. $\left(\mathrm{NH}_{4}\right)_{2} \mathrm{SO}_{4} 0.1 \mathrm{~g}$, $\mathrm{MgSO}_{4} .7 \mathrm{H}_{2} \mathrm{O} 0.25 \mathrm{~g}, \mathrm{KCl} 0.2 \mathrm{~g}, \mathrm{MgCl}_{2} 6 \mathrm{H}_{2} \mathrm{O} 5 \mathrm{~g}, \mathrm{BPB}$ $0.025 \mathrm{~g}$, agar $15 \mathrm{~g}$ dissolved in $1000 \mathrm{ml}$ sterile distilled water [25].

In this study the source of phosphate used came from RP containing: $\mathrm{P}_{2} \mathrm{O}_{5}$ total $30.68 \%, \mathrm{P}_{2} \mathrm{O}_{5}$ available $21.36 \%, \mathrm{P}_{2} \mathrm{O}_{5}$ dissolved citrate acid (2\%) $10-12 \%$, its smoothness passed the sieve $250 \mu \mathrm{m}$. Ability of PSM dissolving RP was done by placing one ose of cultivated PSM in sterile NBRIP-BPB solid media, then incubated for $1-6$ days at room temperature $\left(28^{\circ} \mathrm{C}\right)$. Observation to established halozone (clear zone) by PSM was started a day after the growing. Ability of PSM in dissolving undissolved P could be known by solubilization index (SI) according to formula: total diameter of halozone divided by colony diameter [26] and solubility efficiency (SE) of halozone diameter divided by colony diameter times 100 [27].

$$
\begin{aligned}
& \mathrm{SI}=\text { halo zone diameter } / \text { colony diameter } \\
& \mathrm{SE}=\text { halozone diameter/colony diameter } \times 100
\end{aligned}
$$

\subsection{PSM Ability Test to Dissolve Rock Phosphate in Liquid Media}

Dissolved phosphates due to PSM activity can be known quantitatively by using pikovskaya liquid media i.e., $25 \mathrm{ml}$ (without agar) using RP ( $5 \mathrm{~g} / 1000 \mathrm{ml})$, then was autoclaved at temperature $121^{\circ} \mathrm{C}$ for 20 minutes. PSM $1 \mathrm{ml}\left(1 \times 10^{8}\right.$ $\mathrm{cfu} / \mathrm{ml}$ ) was inoculated into each sterile media for Bacillus sp (JTM3) and Pseudomonas sp (JTM10), whereas Aspergillus niger (JTM2 and JTM6) $1 \mathrm{ml}\left(1 \times 10^{6} \mathrm{cfu} / \mathrm{ml}\right)$. Ability test to dissolve $\mathrm{P}$ was done both at single isolate and combination between bacterial isolate and fungi (Table 2). Treatment then was placed at shaker for 12 days with rotary shaker $120 \mathrm{rpm}$. Suspension was filtered with whatman 40 then centrifuged for 15 minutes at $10.000 \mathrm{rpm}$. Measurement of dissolved P in media was done according to Murphy and Riley [1] using spectrophotometer at the wave length 693 nm calibrated with standard curve $\mathrm{KH}_{2} \mathrm{PO}_{4}$.

\section{Results}

\subsection{Isolation of PSM and Test on Solid Media}

Isolated PSM from rhizosphere of cassava plant, grass and legume from acid soil (Ultisol) at Moncongloe planted in pikovskaya media and NBRIP-BPB (Table 1) shows the growing PSM in pikovskaya media only 2 isolates forming narrow halozone as indicator of the $\mathrm{P}$ solubility. In NBRIP-BPB media all growing colony formed halozone of different diameters. Based on the halozone diameter formed in the NBRIP-BPB media, there are 4 potential isolates dissolving high RP.

Table 1. PSM isolated from grass rhizosphere, cassava and legume in Ultisol Moncongloe, South Sulawesi

\begin{tabular}{lcccc}
\hline No. & \multicolumn{2}{c}{ Media of pikovskaya } & \multicolumn{2}{c}{ Media of NBRIP-BPB } \\
Isolate & colony & halozone & Colony & halozone \\
\hline JTM1 & + & - & + & $\sqrt{ }$ \\
JTM2 & + & $\sqrt{ }$ & + & $\sqrt{ }$ \\
JTM3 & + & - & + & $\sqrt{ }$ \\
JTM4 & + & - & + & $\sqrt{ }$ \\
JTM5 & + & - & + & $\sqrt{ }$ \\
\hline
\end{tabular}




\begin{tabular}{lcccc}
\hline \multirow{2}{*}{$\begin{array}{l}\text { No. } \\
\text { Isolate }\end{array}$} & \multicolumn{2}{c}{ Media of pikovskaya } & \multicolumn{2}{c}{ Media of NBRIP-BPB } \\
colony & halozone & Colony & halozone \\
\hline JTM6 & + & $\sqrt{ }$ & + & $\sqrt{ }$ \\
JTM7 & + & - & + & $\sqrt{ }$ \\
JTM8 & + & - & + & $\sqrt{ }$ \\
JTM9 & + & - & + & $\sqrt{ }$ \\
JTM10 & + & - & + & $\sqrt{ }$ \\
JTM11 & + & - & + & $\sqrt{ }$ \\
\hline
\end{tabular}

Description: $+=$ growing $\sqrt{ }=$ halozone formed $-=$ no halozone formed

In pikovsakaya solid media (Table 1) only 2 isolates formed halozone with small diameter whereas in NBRIP-BPB the formed halozone was clear and had bigger diameter. Based on the formed halozone, there are 4 high potential isolates which can dissolve P: isolate Bacillus sp
JTM3, isolate Pseudomonas sp JTM10, isolate Aspergillus niger JTM2 and isolate Aspergillus niger JTM6. Four isolates which have big halozone diameter was then tested in NBRIP-BPB media to measure the solubility index (SI) and the solubility efficiency (SE) toward RP. Halozone diameter from group of bacteria (Bacillus sp and Pseudomonas sp) formed was smaller $(2.10-2.23 \mathrm{~cm})$ than the Aspergillus niger fungi halozone diameter $(6.57-8.50 \mathrm{~cm})$ measured at the age of 5 days, but the SI and the SE of bacteria were bigger than the fungi (Table 2).

\subsection{PSM Ability Test in Pikovskaya Liquid Media}

Ability test in dissolving RP quantitatively from 4 isolates was done by using liquid pikovskaya media containing $5 \%$ RP. This observation shows the lowering $\mathrm{pH}$ of liquid media inoculated by PSM both in the treatment of single isolate and mixed isolates compared to control $\mathrm{pH}$.

Table 2. Solubility index and solubility efficiency of RP by PSM in NBRIP-BPB media

\begin{tabular}{|c|c|c|c|c|c|}
\hline Microbia & $\begin{array}{c}\text { Age of isolate } \\
\text { (day) }\end{array}$ & $\begin{array}{c}\text { Diameter of colony } \\
(\mathrm{cm})\end{array}$ & $\begin{array}{c}\text { Diameter of } \\
\text { Halozone (cm) }\end{array}$ & solubility index & solubility efficiency \\
\hline \multirow{3}{*}{ Bacillus sp JTM3 } & 2 & 0,95 & 1,58 & 1,67 & 166,67 \\
\hline & 3 & 1,05 & 1,78 & 1,70 & 169,84 \\
\hline & 4 & 1,07 & 2,00 & 1,88 & 187,50 \\
\hline \multirow{11}{*}{ Pseudomonas sp JTM10 } & 5 & 1,10 & 2,23 & 2,03 & 203,03 \\
\hline & 6 & 1,10 & 2,62 & 2,38 & 237,88 \\
\hline & 7 & 1,12 & 2,73 & 2,45 & 244,78 \\
\hline & Average & & & 2,02 & 201,62 \\
\hline & 2 & 0,70 & 1,18 & 1,69 & 169,05 \\
\hline & 3 & 0,92 & 1,85 & 2,02 & 201,82 \\
\hline & 4 & 0,95 & 2,00 & 2,11 & 210,53 \\
\hline & 5 & 0,98 & 2,10 & 2,14 & 213,56 \\
\hline & 6 & 1,02 & 2,27 & 2,23 & 222,95 \\
\hline & 7 & 1,03 & 2,42 & 2,34 & 233,87 \\
\hline & Average & & & 2,09 & 208,63 \\
\hline \multirow{4}{*}{ Aspergillus niger JTM2 } & 2 & 2,00 & 2,75 & 1,38 & 137,50 \\
\hline & 3 & 2,50 & 4,05 & 1,62 & 162,00 \\
\hline & 4 & 3,45 & 5,37 & 1,56 & 155,56 \\
\hline & 5 & 4,38 & 6,57 & 1,50 & 149,81 \\
\hline \multirow{8}{*}{ Aspergillus niger JTM6 } & 6 & 5,23 & 7,98 & 1,53 & 152,55 \\
\hline & Average & & & 1,51 & 151,48 \\
\hline & 1 & 1,20 & 2,25 & 1,88 & 187,50 \\
\hline & 2 & 2,48 & 3,88 & 1,57 & 156,57 \\
\hline & 3 & 3,35 & 5,30 & 1,58 & 158,21 \\
\hline & 4 & 4,35 & 7,15 & 1,64 & 164,37 \\
\hline & 5 & 5,40 & 8,50 & 1,57 & 157,41 \\
\hline & Average & & & 1,65 & 164,81 \\
\hline
\end{tabular}

Higher solubility of RP was not always correlated with lower $\mathrm{pH}$. Isolate of JTM2 (pH 4.01) the dissolved RP was only $19.14 \mathrm{mg} \mathrm{P}^{-1}$. On the contrary, isolate JTM10 (pH
6.64), the dissolved RP was $76.33 \mathrm{mg} \mathrm{P} \mathrm{l}^{-1}$. Correlation between low $\mathrm{pH}$ and the RP solubility can be shown by the treatment of mixture of isolate JTM2 and isolate JTM3. The 
RP solubility increased clearly due to PSM incubation compared to control (Table 3) except for the treatment of isolate JTM3 and mixture of isolate JTM $2+3+6$ was not different significantly from the control based on Duncan test at the level of significance $95 \%$. This result of this study shows synergy between isolate JTM2 and JTM3 because the RP solubility of single treatment was only $19.14 \mathrm{mg} \mathrm{Pl}^{-1}$ and $7.49 \mathrm{mg} \mathrm{Pl}^{-1}$ respectively, whereas the treatment mixture of isolate JTM2 and dissolved JTM3 RP increased to $87.59 \mathrm{mg}$ $\mathrm{Pl}^{-1}$.

Table 3. $P$ solubility from RP and $p H$ change by PSM in Pikovskaya liquid media

\begin{tabular}{|c|c|c|c|c|}
\hline No. & Treatments & $\begin{array}{l}\text { Average pH } \\
\text { liquid media }\end{array}$ & $\begin{array}{c}\text { Averag } \\
\text { soluble }\end{array}$ & $\begin{array}{l}\text { e P } \\
\left(\mathrm{mg} \mathrm{P} \mathrm{l}^{-1}\right)\end{array}$ \\
\hline 1 & Isolate JTM2 & 4,01 & 19,14 & $\mathrm{~b}$ \\
\hline 2 & Isolate JTM3 & 5,52 & 7,49 & a \\
\hline 3 & Isolate JTM6 & 5,97 & 66,47 & de \\
\hline 4 & Isolate JTM10 & 6,64 & 76,33 & e \\
\hline 5 & Isolate JTM2 + 3 & 4,74 & 87,59 & $\mathrm{f}$ \\
\hline 6 & Isolate JTM3 + 6 & 5,99 & 32,51 & $\mathrm{~b}$ \\
\hline 7 & Isolate JTM2 + 10 & 5,34 & 29,12 & $\mathrm{~b}$ \\
\hline 8 & Isolate JTM6 + 10 & 5,90 & 18,86 & $\mathrm{~b}$ \\
\hline 9 & Isolate JTM2 $+3+6$ & 6,32 & 6,57 & a \\
\hline 10 & Isolate JTM2 $+6+10$ & 5,77 & 68,90 & de \\
\hline 11 & Isolate JTM $2+3+10$ & 6,19 & 59,34 & $\mathrm{c}$ \\
\hline 12 & Isolate JTM3 $+6+10$ & 6,61 & 67,23 & de \\
\hline 13 & Isolate JTM2 $+3+6+10$ & 6,49 & 59,40 & $\mathrm{~cd}$ \\
\hline 14 & Control (without PSM) & 7,16 & 0,18 & $\mathrm{a}$ \\
\hline
\end{tabular}

\section{Discussion}

\subsection{PSM in Solid Media}

Based on the selection in pikovskaya solid media, the formed halozone was only small so that it was difficult to identify the formation of halozone clearly from PSM colony. In order to overcome the difficulty, the test was done in NBRIP-BPB media [25]. Nautiyal [28], found that the use of yeast extract in pikovskaya media inhibit the growth of PSM In the same case based on our experiment, we found that NBRIP-BPB media can form halozone that was clearer. This properties is helpful in identifing PSM that can solubilize phosphate. This one of superiority of NBRIP-BPB media comparing to pikovskaya media.

This observation to colony diameter and halozone diameter in NBRIP-BPB media toward 4 PSM isolates shows Aspergillus niger (JTM2 and JTM6) was bigger compared to Bacillus sp JTM3 and Pseudomonas sp JTM10, but the observation of SI and SE shows Bacillus sp JTM3 and Pseudomonas sp JTM10 was higher compared to Aspergillus niger JTM2 and Aspergillus niger JTM6. The average values SI and SE of bacteria were 2.05 and 205.12 respectively, whereas JTM2 and JTM6 were 1.58 and 158.14 respectively. This indicates that the bacteria dissolve higher
$\mathrm{P}$ than Aspergillus. Ability of bacteria to dissolve higher $\mathrm{P}$ than fungi also has been reported before [20, 23].

Observation to SI and SE in solid media was an early selection to microorganism that can dissolve $\mathrm{P}$ qualitatively. Therefore further test is still needed in liquid media, because in solid media it has not reflected the power of dissolving $\mathrm{P}$ quantitatively. Besides the amount of SI and SE may not reflect the power to dissolve RP in pikovskaya liquid media $[29,30]$. The same thing happens at the observation of SI and SE in isolate JTM 3 was $2.02 \mathrm{~cm}$ and 201.62 but dissolved $P$ in liquid media was only $7.49 \mathrm{mg} \mathrm{Pl}^{-1}$. On the contrary, isolate JTM 6 has SI and SE 1.65 and 164.81 but dissolved P was $66.47 \mathrm{mg} \mathrm{Pl}^{-1}$.

\subsection{PSM in Pikovskaya Liquid Media}

Theory of P solubility by PSM in liquid media refers to production of organic acid, lowering of $\mathrm{pH}$ and the chelation to cations by organic acid so that $\mathrm{P}$ becomes dissolve. This observation shows that all PSM treatments have low $\mathrm{pH}$ between 4.01 and 6.64 both in single treatment and mixed treatment; whereas in control (without PSM) the $\mathrm{pH}$ was 7.16. Lowering of $\mathrm{pH}$ in media in PSM treatment is due to production of organic acid [31] and by PSM respiration [14]. Lowering of $\mathrm{pH}$ accompanied by production of organic acid will increase $\mathrm{P}$ solubility.

Negative correlation between $\mathrm{pH}$ and $\mathrm{P}$ solubility in this study can be seen in treatment JTM2+JTM3, JTM2+JTM6+JTM10 and JTM 6 of which the pH was 4.74, 5.77 and 5.97 respectively. Dissolved $\mathrm{P}$ was $87.59 \mathrm{mg} \mathrm{Pl}^{-1}$, $68.90 \mathrm{mg} \mathrm{Pl}^{-1}$ and $66.47 \mathrm{mg} \mathrm{Pl}^{-1}$ respectively. The increase of $\mathrm{P}$ solubility was due to the lowering of $\mathrm{pH}$ accompanied by organic acid production $[13,8]$. However, some researchers indicate that there is no correlation between $\mathrm{pH}$ and $\mathrm{P}$ solubility [14-18]. The same thing is also indicated by this study that is in the treatment of single isolate JTM10 and mixed isolates JTM3+JTM6+JTM10, the $\mathrm{pH}$ was 6.64 and 6.61 respectively but the RP solubility was higher than some treatments of low $\mathrm{pH}$. According to Illmer and Schinner [14], $\mathrm{P}$ solubility in relatively high $\mathrm{pH}$ was due to chelation of organic acid with ion $\mathrm{Ca}$ in tricalcium phosphate. Result of this study also shows the treatment of single isolate JTM2 and JTM3 can dissolve RP only $19.14 \mathrm{mg} \mathrm{Pl}^{-1}$ and $7.49 \mathrm{mg}$ P1-1 respectively, but in mixed treatment between isolate JTM2 and JTM3 the RP solubility increased to $87.59 \mathrm{mg}$ $\mathrm{Pl} 1$, so there was a synergic effect between the two. Existence of synergy may be caused by resultant between the lowering of $\mathrm{pH}$ and production of organic acid due to mixture of isolates JTM3 +JTM2. Mixture of isolates JTM2 and JTM3 caused the lowering of $\mathrm{pH}$ of isolate JTM3. Lowering of $\mathrm{pH}$ caused the change of organic acid produced was more dominant citrate acid [32]. Citrate acid has power to dissolve $\mathrm{P}$ greater than oxalic acid and malate [23].

\section{Conclusion}

The use of NBRIP-BPB media makes observation of SI and SE values possible and clear compared to pikovskaya 
media. The values of SI and SE of Bacillus sp JTM3 and Pseudomonas sp JTM10 are bigger than Aspergillus niger JTM2 and JTM6 planted in NBRIP-BPB solid media. Test of PSM in solid media through observation of SI and SE has not reflected the ability to dissolve $\mathrm{P}$ because it is not always compatible with quantitative test in liquid media. In pikovskaya liquid media the single isolate Pseudomonas sp JTM10 and mixed isolates between Aspergillus niger JTM2 and Bacillus sp JTM3 is found to be more effective in dissolving $\mathrm{P}$.

\section{Acknowledgments}

The authors would like to thank you for the opportunity given to research in the Laboratory of Soil Microbiology at the Department of soil science and the Laboratory of Research Center for Biotechnology, Hasanuddin University, Makassar, Indonesia

\section{References}

[1] J. Murphy, And J. R. Riley, A Modified solution method for determination of phosphate in natural water, vol. 27. Analytical Chimica Acta, 1962, pp. 31-36.

[2] A. Mulyani, A. Rachman and A. Dairah," Penyebaran lahan masam, Potensi dan ketersediaannya untuk pengembangan pertanian," in Pemanfaatan fosfat alam sebagai sumber pupuk P. Balai Penelitian Tanah. Puslittanak, Bogor, 2009, pp, $23-44$.

[3] J. Adiningsih dan M. Sudjadi, "Peranan sistem bertanam lorong (Alley cropping) dalam meningkatkan kesuburan tanah pada lahan kering masam." Risalah Seminar Hasil Penelitian Tanah dan Agroklimat. Pusat Penelitian Tanah dan Agroklimat, Bogor. 1993, unpublished.

[4] H. G. Soepardi,"Strategi usahatani agribisnis berbasis sumber daya lahan", in Prosiding Nasional Pengelolaan Sumber daya Lahan dan Pupuk Buku I. Pusat Penelitian dan Pengembangan Tanah dan Agroklimat, Bogor. 2001, pp. $35-52$

[5] H. M. Hosseini, S. Kayami, H. Besharati and S. Bybordi, "Study of the effects of rock phosphate application with phosphate solubilizing bacteria on P availability for corn," world congress of Soil Science, Soil Solutions for Changing World, August 2010.

[6] K. F. Isherword, "Fertilizer use and environment". In Proc. Symp. Plant Nutrition Management for Sustainable Agricultural Growth.. N. Ahmed and A. Hamid (eds.), Islamabad: NFDC, 1998. pp. 57-76.

[7] J.K Vessey, K. Pawlowski and B. Bergman, Root-based $\mathrm{N}_{2}$-fixing symbioses: Legumes, actinorhizal plants, Parasponia sp., and cycads, vol. 266. Plant and Soil, 2004, pp. $205-230$.

[8] H, N. Fankem, N. Laurette, D. Annette, Q. John, M. Wolfgang, E. François-Xavier., and N. Dieudonné. Solubilization of inorganic phosphates and plant growth promotion by strains of Pseudomonas fluorescens isolated from acidic soils of Cameroon, vol. 2. African J. Microbiol. Res, 2008, pp. 171-178.
[9] E. Premono, M. A. Moawad and P. L. G. Vleck, Effect of phosphate solubilizing Pesudomonas putida on the growth of maize and its survival in the rhizosphere, vol. 11. Indonesian Journal of Crop Science, 1996, pp. 13-23.

[10] J. M. Igual, A. Valverde, E. Cervantes and E. Velázquez.. Phosphate-solubilizing bacteria as inoculants for agriculture: use of updated molecular techniques in their study, vol. 21. Agronomie, 2001, pp. 561-568.

[11] I. Anas, E. Premono dan R. Widyastuti. "Peningkatan Efisiensi Pemupukan $\mathrm{P}$ dengan Menggunakan Mikroorganisme Pelarut P.” Pusat antar Universitas IPB. Bogor. 1993..unpublished.

[12] P. Lestari, "Pengaruh fungi pelarut fosfat terhadap serapan hara P dan Peertumbuhan Tanaman Jagung." Skripsi. Fakultas Pertanian IPB. Bogor. 1994. unpublished.

[13] M. Rashid, S. Khalil, N. Ayub, S. Alam and F. Latif. Organic acids production and phosphate solubilizing microorganisms (SM) under invitro condition, vol.7 (2). Pakistan Journal of Biological Sciences, 2004. pp. 187 - 196.

[14] P. Illmer, and F.Schinner, Solubilization of inorganic phosphate by microorganisms isolated from forest soils., vol 24. Soil Biol. Biochem, 1992, pp. 389-395.

[15] P. E. A. Asea, R. M. N. Kucey and J. W. B. Stewart. Inorganic phosphate solubilization by two Penicillium species in solution culture and soil, vol. 20. Soil Biol. Biochem, 1988, pp. $459-464$.

[16] H. M. Salih, A. I. Yahya, A. M. Abdul-Rahman and B. H. Munam. Avallability of phosphorus in a calcareous soil treated with rock phosphate or super phosphate or effected by phosphate dissolving fungi, vol. 20. Plant soil, 1989, pp. $181-185$.

[17] M. A. Whitelaw, T.J. Harden and K.R. Helyar, Phosphate solubilization in solution culture by the soil fungus Penicillium radicum, vol. 31. Soil Biol. Biochem, 1999, pp. 655-665.

[18] V. Narsian, Takkar, J. and Patel, H.H. Mineral phosphate solubilization by Aspergillus aculeatus. Indian J. Expt. Biol, 1995, pp. 33, 91.

[19] D. H. Goenadi, and R. Saraswati. Kemampuan melarutkan fosfat dari beberapa isolat fungi pelarut fosfat, vol, 61(3). Menara Perkebunan, 1993, pp. $61-66$.

[20] Alam S., S. Khalil, N. Ayub and M. Rashid. In vitro solubilization of inorganic phosphate by phosphate solubilizing microorganism (PSM) from maize rhizosphere, vol. 4. No. 4. Int. J. Agric. Biol, 2002, pp. 454-458.

[21] Z. L. He, W. Bian and J. Zhu. Screening and identification of microorganisms capable of utilizing phosphate adsorbed by goethite, vol. 33. Comm. Soil Sci. Plant Anal, 2002, pp. 647-663.

[22] Y. Sastro, D. Widianto,and D. Shiddieq. Secretion of organic acids by Aspergillus niger YD 17 that grown with rock phosphate, vol. XI (3). Biota, 2006, pp. 167 - 175.

[23] Y.P. Chen, P. D. Rekha., A. B. Arun., F. T. Shen., W. A. Lai., and C. C. Young, Phosphate solubilizing bacteria from subtropical soil and their tricalcium phosphate solubilizing abilities, vol. 34. Applied Soil Ecology, 2006, pp. 33 - 41. 
[24] N.S.. Subba Rao, "Biofertilizer in Agricultural," Oxford and IBH Publishing Co. New Delhi. Bombai. 1982, pp. 186.

[25] C. S. Nautiyal, S. Mehta and P. Pushpangadan. "Composition for Qualitative Screening of Phosphate Solubilizing Microorganisms and a Qualitative Method for Screening Microorganisms." Council of Scientific and Industrial Research, New Delhi. October 2003.

[26] O. J. Chibuogwu and E. H. Nmesoma,. Bath culture studies of Phosphate solubilisation by Micrococcus sp PSB 7 isolated from rhizospheric soil, vol. 10 (4). American-Eurasian J. Agric and Environ. Sci, 2011, pp. $667-674$

[27] K. Sharma, G. Dak, A. Agrawal, M. Bhatnagar and R. Sharmar, Effect of phosphate solubilizing bacteria on the germination of cicer arietinum seeds and seedling growth, vol. I(1). J. Herb. Med.Toxicol, 2007, pp. $61-63$.

[28] C. S. Nautiyal, An efficient microbiological growth medium for screening phosphate solubilizing microorganisms, vol.170. FEMS Microbiol. Letters, 1999. pp. 265-70.

[29] R. Gupta, S. Rekha, S. Aparna. and R.C. Kuhad, A modified plate assay for screening phosphate solubilizing microorganisms, vol. 40. J. Gen. Appl. Microbiol, 1994, pp. 255-260.

[30] El-Azeem, S.A.M., T. A. Mehana and A. A. Shabayek, Some plant growth promoting traits rhizobacteria isolated from Suez Canal region, Egypt, vol. 8. African Crop Science Society. Proceedings, 2007, pp.1517-1525.

[31] A. E. Richardson, J. M. Barea, A. M. McNeill, C. Prigent-Combaret, Acquisition of phosphorus and nitrogen in the rhizosphere and plant growth promotion by microorganisms, vol. 321. Plant Soil, 2009, pp. 305-339.

[32] D. V. Guebel and N. V. T. Darias, Optimization of the citric acid production by Aspergillus niger through a metabolic Flux balance model, vol. 4. J. Biotechnol, 2001, pp.1-12. 